
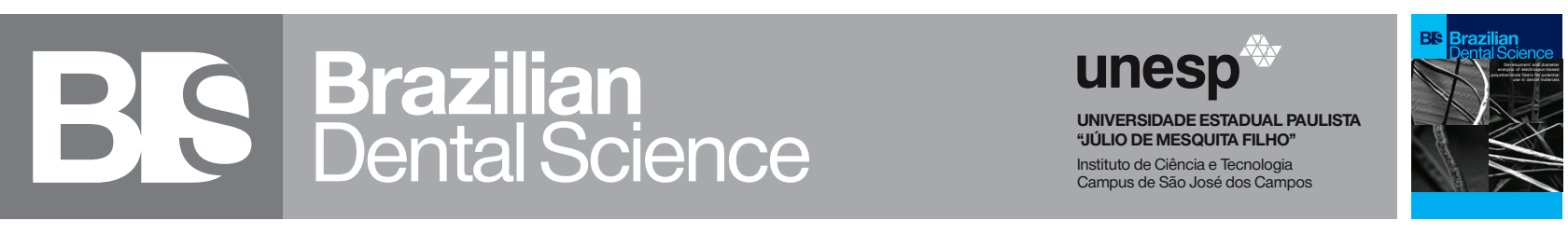

\title{
Antibacterial Potentials of some Toothpaste Products against some Oral Bacterial Isolates
}

\author{
Potencial ação antibacteriana de produtos de pastas de dentes contra isolados bacterianos orais \\ Oluboyo B. OLUWAPELUMI ${ }^{1}$, Maihankali J. CHARLES ${ }^{1}$, Akele R.YOMI' ${ }^{1}$, Akinseye J. FUNMILAYO ${ }^{1}$, Oluboyo O. ADEOLA \\ 1 - Department of Medical Laboratory Science, Afe Babalola University, Ado- Ekiti, Ekiti State, Nigeria.
}

\section{ABSTRACT}

Objetive: Manufacturers of toothpastes claim that their products are active against oral microbiome capable of causing tooth decay. The objective of this study was to investigate the manufacturers' claim using some of the toothpaste products sold in Ado-Ekiti, Nigeria. Material and methods: The antibacterial potentials of five commercialized toothpaste products (designated sodium fluoride-zinc sulphate, benzyl alcohol-sodium fluorophosphate, sodium fluoride-eugenol, sodium fluoridesodium laurylsulfate and sodium fluoridepotassium nitrate) were tested against six oral isolates of dental caries and periodontal origin - Staphylococcus aureus, Streptococcus mitis, Streptococcus salivarius, Streptococcus pyogenes and Pseudomonas aeruginosa. The antimicrobial potentials were evaluated using modified agar well diffusion method. Various dilutions of the toothpaste products from 1:1 to $1: 16$ were tested against each test microorganism. The minimum inhibitory concentration (MIC) and minimum bactericidal concentration (MBC) of the toothpastes were determined. Results: sodium fluoride-zinc sulphate, benzyl alcoholsodium fluorophosphate and sodium fluorideeugenol toothpastes showed inhibitory effects on $S$. aureus, $S$. mitis and $S$. salivarius. Sodium fluoride-sodium laurylsulfate and sodium fluoride-potassium nitrate toothpastes showed no inhibitory effect on the organisms except $S$. pyogenes. Only sodium fluoride-potassium nitrate toothpaste inhibited $E$. coli while none of the toothpastes inhibited $P$. aeruginosa. The

\section{RESUIO}

Objetivo: Os fabricantes de dentifrícios afirmam que seus produtos são ativos contra a microbiota oral capaz de causar cáries. O objetivo deste estudo foi investigar a justificativa dos fabricantes sobre o uso de alguns produtos na pasta de dente vendida em Ado-Ekiti, Nigeria. Materiais e métodos: Os potenciais agentes antibacterianos dos cinco produtos de creme dental comercializados (denominados fluoreto de sódio-sulfato de zinco, álcool benzilico-fluorofosfato de sódio, fluoreto de sódio-eugenol, fluoreto de sódio-laurilsulfato de sódio-nitrato de potássio) foram testados contra 06 isolados orais de cárie dentária e origem periodontal - Staphylococcus aureus, Streptococcus mitis, Streptococcus salivarius, Streptococcus piogenes e Pseudomonas aeruginosa. Os potenciais antimicrobianos foram avaliados usando o método de difusão em ágar modificado. Várias diluições dos produtos das pastas de dente de $1: 1$ a $1: 16$ foram testadas contra cada microorganismo citado. A concentração inibitório mínima (MIC) e a concentração bactericida mínima (CBM) das pastas de dente foram determinadas. Resultados: As pastas de fluoreto de sódiosulfato de zinco, álcool benzilico-fluorofosfato de sódio e fluoreto de sódio-eugenol apresentaram efeitos inibitórios sobre $S$. aureus, S. mitis, $S$. salivarius. Os dentifrícios com fluoreto de sódiolaurilsulfato de sódio e fluoreto de sódio-nitrato de potássio não mostraram efeito inibitório sobre os microorganismos, exceto S. pyogenes. Apenas o creme dental com fluoreto de sódio e nitrato de potássio inibiu a $E$. coli, enquanto nenhum dos dentifrícios inibiu a P. aeruginosa. O MIC e CBM de 
MIC and MBC of sodium fluoride-zinc sulphate, benzyl alcohol-sodium fluorophosphate, and sodium fluoride-eugenol toothpastes showed bacteriostatic and bactericidal effects on the organisms. Sodium fluoride-zinc sulphate, benzyl alcohol-sodium fluorophosphate, and sodium fluoride-eugenol toothpastes showed comparable effects on $S$. aureus, $S$. mitis and $S$. salivarius. Sodium fluoride-eugenol toothpaste was strongest against $S$. mitis, benzyl alcoholsodium fluorophosphates toothpaste was strongest against $S$. pyogenes, sodium fluoridezinc sulphate toothpaste was strongest against S. salivarius and only sodium fluoride-potassium nitrate toothpaste inhibited $E$. coli. Conclusion: The manufacturer's claim is upheld by this study for sodium fluoride-zinc sulphate, benzyl alcohol-sodium fluorophosphate and sodium fluoride-eugenol toothpastes. However, sodium fluoride-sodium laurylsulfate and sodium fluoride-potassium nitrate toothpastes showed limited inhibitory potentials.

\section{KEYWORDS}

Antibacterial; Caries; Oral isolates; Periodontitis; Toothpastes. fluoreto de sóido-sulfato de zinco, álcool benzilicofluorofosfato de sódio e dentifrício fluoreto de sódio-eugenol mostraram efeitos bacteriostáticos e bactericidas sobre os organismos. As pastas de fluoreto de sódio-sulfato de zinco, álcool benzilicofluorofosfato de sódio-eugenol mostraram efeitos comparáveis em $S$. aureus, $S$. mitis e $S$. salivarius. O creme dental com fluoreto de sódio-eugenol foi o mais forte contra S. mitis, o creme dental com álcool benzilico e fluorofosfatos de sódio foi o mais forte contra $S$. pyogenes, o creme dental com fluoreto de sódio-sulfato de zinco foi o mais forte contra o $S$. salivarius e apenas o creme dental com fluoreto de sódio-nitrato de potássio inibiu $E$. coli. Conclusão: A utilização de alguns produtos pelo fabricante é confirmada por este estudo para as pastas de dente com fluoreto de sódio-zinco, álcool benzilico-fluorofosfato de sódio e fluoreto de sódio-eugenol. No entanto, os dentifrícios com fluoreto de sódio-laurilsulfato de sódio e fluoreto de sódio-nitrato de potássio apresentaram potencial inibitório limitado.

\section{PALAVRAS-CHAVE}

Antibacteriano; Cáries; Isolados bucais; Periodontites; Pasta de dente.

\section{INTRODUCTION}

$\mathrm{R}$ esearchers reported that different oral structures and tissues are inhabited by distinct microbial agents [1,2], some of which are capable of causing diseases. The sustained prevalence of oral diseases worldwide suggests that ideal oral hygiene is not achieved or maintained, requiring the use of toothpaste containing antimicrobial substances and routine brushing in order to increase the inhibitory actions on oral microorganisms. [3]. Fluoride toothpastes are more commonly used for caries control. The massive promotion of fluoride toothpastes by the oral healthcare industry is the major reason for their increased use, and, almost all commercially available toothpaste formulations contain fluoride [4]. Most researchers and public health authorities regard fluoride toothpastes as the method of choice for the prevention of dental caries because they are convenient and culturally accepted, widely used, and are commonly associated with decline in caries prevalence in many countries [5]. Triclosan in toothpastes has been reported to reduce the viability of bacteria in vivo and decreases gingival and plaque index scores $[6,7]$.

The two major diseases that affect the teeth are caries (decay) and periodontitis, with gingivitis as the milder form of gum disease. Untreated gum disease can result to periodontitis [8]. Of the wide variety of oral bacteria, 
Streptococcus mutans, E. coli, Pseudomonas aeruginosa and Lactobacillus species are among the specific species of bacteria that are believed to cause dental caries [9]. Bacteria classified as periodontal pathogens include Porphyromonas gingivalis, Actinobacillus actinomycetemcomitans, P. aeruginosa, E. coli, Staphylococcus species, Klebseilla pneumoniae, Streptococcus species, Tannerella forsythia, Treponema denticola, $[10,11]$. These bacteria are documented in larger numbers in patients with periodontal diseases and have hardly ever been isolated from healthy subjects [10]. S. mitis occupy hard surfaces in the oral cavity and are part of the oral flora. $S$. mitis is usually a cause of odontogenic infection and endocarditis and only in some cases has it been recognized as respiratory pathogen [12]. $S$. salivarius is most often harmless but is considered an opportunistic pathogen [13]. S. pyogenes often starts infection on the surface of the skin or in the throat spreading into deeper areas of the skin, which can potentially lead to life-threatening diseases [14]. S. aureus is however not always pathogenic, it is a common cause of skin infections including abscesses, respiratory infections such as sinusitis. It can cause various skin and soft tissue infections [15], particularly when skin or mucosal barriers have been breached.

Antimicrobials and their concentrations in different products of toothpastes may contribute to the effectiveness of the toothpastes. It is therefore pertinent to find out the inhibitory potentials of the different products of toothpastes to investigate their ability to decrease bacterial load in human oral cavity to know if they contribute to dental health. Labels on toothpastes indicate that the products have antimicrobial properties capable of reducing oral microorganisms causing dental caries. Hence the present study aimed to investigate antimicrobial efficacy of different toothpaste products sold in Ado-Ekiti against oral bacteria isolates.

\section{MATERIALS AND METHODS}

\section{Study Area}

The study was conducted in Ado-Ekiti, Ekiti State, Nigeria. Ado-Ekiti lies on latitude 7.62 and longitude 5.22 with coordinates $7^{\circ} 37^{\prime}$ $\mathrm{N}$ and $5^{\circ} 13^{\prime} \mathrm{E}$. The city has elevation of $455 \mathrm{~m}$ with population of 424,340 [16]. It has an area of $36.7 \mathrm{Km} 2$ [17].

\section{Toothpaste products under study}

Five common toothpaste products were investigated. They were designated sodium fluoride-zinc sulphate, benzyl alcohol-sodium fluorophosphate, sodium fluoride-eugenol, sodium fluoride-sodium laurylsulfate and sodium fluoride-potassium nitrate toothpastes. Table I shows the composition contained in the labels of each toothpaste, as well as the active ingredients, registered according to the manufacturers.

\section{Identification and Storage of isolates}

The tested microorganisms were E. coli, $S$. aureus, $P$. aeruginosa, $S$. pyogenes, $S$. mitis, and $S$. salivarius. They were oral isolates of dental caries collected from Ekiti State University Teaching Hospital, Ado-Ekiti and Federal Teaching Hospital, Ido-Ekiti, Ekiti State.

The streptococci were cultured on blood agar - blood agar base, REF: LAB 028, LOT 139468/182 (Lab M Ltd, Lancashire, United Kingdom), chocolate agar and mitis salivarius agar - Difco ${ }^{\mathrm{TM}}$ mitis salivarius agar BD, REF 229810, LOT 7325810 (Becton, Dickinson and Co., Sparks, USA) for cultural identification, and further tests for the confirmation of their identity. $S$. aureus, $P$. aeruginosa and $E$. coli were cultured on MacConkey agar - REF M008S-500G, LOT 0000353107(HiMedia Laboratories Pvt. Ltd, Mumbai, India). S. aureus was identified by its pinkish discrete colony on MacConkey agar, Gram positive cocci in clusters with catalase and coagulase positive reactions. P. aeruginosa and $E$. coli were characterized using standard microbiology and biochemical tests and identified according to standard methods [18-23]. The pure cultures of $S$. aureus, $P$ aeruginosa and $E$. coli were stored and maintained in nutrient agar 
- REF M001-500G, LOT 0000353173 (HiMedia Laboratories Pvt. Ltd, Mumbai, India United Kingdom) slants, while streptococci were stored on brain heart infusion agar - REF M211-500G, LOT 0000304449 (HiMedia Laboratories Pvt. Ltd, Mumbai, India) at $4{ }^{\circ} \mathrm{C}$ until they are ready for use. isolates

Preparation of inoculums of selected

Isolates of the microorganisms were picked from the slant with an inoculating wire loop and suspended in $5 \mathrm{ml}$ of peptone water - REF M028500G, LOT 0000338533 (HiMedia Laboratories Pvt. Ltd, Mumbai, India) and incubated overnight at $37^{\circ} \mathrm{C}$ to reactivate the organisms. The resulting turbidity was adjusted to $0.5 \mathrm{McF}$ arland turbidity standards [24].

\section{Preparation of toothpastes for antimicrobial assay}

Ten grammes (10 grams) of each of the selected toothpaste products was dissolved in $10 \mathrm{ml}$ of sterile distilled water to obtain a concentration of 1:1 (1 grams / ml or $1000 \mathrm{mg}$ $/ \mathrm{ml}$ ), that was further diluted serially to obtain concentration of $1: 2,1: 4,1: 8,1: 16$ corresponding to $500 \mathrm{mg} / \mathrm{ml}, 250 \mathrm{mg} / \mathrm{ml}, 125 \mathrm{mg} / \mathrm{ml}, 62.5$ $\mathrm{mg} / \mathrm{ml}$ respectively.

\section{Determination of antibacterial susceptibility of tested microorganisms}

The antibacterial activity of different concentrations of the tothpastes were determined by modified agar well diffusion method $[19,25]$. Mueller-Hinton agar - REF M173-500G, LOT 0000341708 (HiMedia Laboratories Pvt. Ltd, Mumbai, India) and brain heart infusion agar plates were prepared aseptically following the manufacturer's instructions. The agar plates were seeded with $0.5 \mathrm{ml}$ of the standard inoculum of each microorganism and allowed to dry for 1 hour. Brain heart infusion agar was used for streptococcus strains.

A sterile $6 \mathrm{~mm}$ cork borer was used to punch one central and five wells of $6 \mathrm{~mm}$ diameter at equidistance in each of the plates. The holes were labeled with dilutions to be inserted and $0.2 \mathrm{ml}$ of the toothpaste dilutions $(1 / 1,1 / 2$, $1 / 4,1 / 8$, and $1 / 16$ ) were introduced into each of five wells, while $5 \mu \mathrm{g}$ ciprofloxacin disc - LOT SC09/P (Abtek Biologicals Ltd, Liverpool, United Kingdom) was placed on the agar surface to serve as positive control. Sterile distilled water $(0.2 \mathrm{ml})$ was introduced into the central wells to serves as negative controls. The plates were incubated at $37^{\circ} \mathrm{C}$ for 24 hours. The tests were interpreted as valid by growth of microorganisms to the tip of distilled water wells and the microorganisms were inhibited by ciprofloxacin. The antibacterial activities of the toothpastes were evaluated by measuring the diameter of zones of inhibition minus the diameter of the well $(6 \mathrm{~mm})$. The experiments were done in triplicates and the mean zones of inhibition were recorded.

\section{*Determination of minimum inhibitory concentration (MIC)}

MIC values were determined by the broth tube dilution method $[19,20]$. The toothpaste was diluted and added to the brain heart infusion broth supplemented with 2 grams / liter of glucose $(0.2 \%)$ with 2 times the final concentration and the tested concentrations were from $1000 \mathrm{mg} /$ $\mathrm{ml}$ to $15.6 \mathrm{mg} / \mathrm{ml}$. One drop of the standardized inoculum of each bacterium was used in each test. A tube containing brain-heart infusion broth and inoculated with S. aureus was included in the test to be sure that the prepared broth supports the growth of microorganisms. Furthermore, a tube containing toothpaste dilution and broth that is not inoculated with S. aureus, and another tube containing only the broth that is not inoculated with $S$. aureus were included in the test to show the sterility and clarity of the broth [25]. A drop of $0.2 \%$ phenol red was added to all the tubes [20] and incubated at $37 \mathrm{oC}$ for 24 hours for bacterial cultures. With satisfactory controls, the tubes were checked for evidence of growth - change in color from red to yellow and / or turbidity at the supernatant [20] after incubation. The lowest concentration of the toothpaste dilution that inhibited the growth of the tested microorganism was recorded as the MIC [19]. 


\section{Determination of minimum bactericidal concentration (MBC)}

Minimum bactericidal concentration was determined from MIC. From the tubes showing no visible growth, $0.1 \mathrm{ml}$ of the samples were inoculated on the sterile brain heart infusion agar using streak plate method. The plates were incubated at $37^{\circ} \mathrm{C}$ for 24 hours. The least concentration that did not show any growth of the tested microorganism was recorded as the MBC $[19,25]$.

\section{RESULTS}

The tested microorganisms grew to theedges of the wells $(0.0 \mathrm{~mm})$ containing distilled water while several zones of inhibition were observed against the bacteria tested with ciprofloxacin (table II). The microorganisms were inhibited by toothpastes according to the concentration used. Wider zones of inhibition were recorded at higher concentrations than at lower concentrations of toothpaste, that is, they were dose dependent. Based on the diameter of inhibition at various dilutions, sodium fluoride-zinc sulphate, benzyl alcohol-sodium fluorophosphate, and sodium fluoride-eugenol toothpastes showed comparable antibacterial potential against $S$. aureus, $S$. mitis and $S$. salivarius. S. mitis was most inhibited by sodium fluoride-eugenol toothpaste. Sodium fluoride-zinc sulphate toothpaste inhibited $S$. aureus, S. mitis, S. salivarius and S. pyogenes, with $S$. aureus and $S$. salivarius being inhibited until the 1: 8 dilution, which corresponds to the concentration $125 \mathrm{mg} / \mathrm{ml}$ and $S$ mitis and $S$. pyogenes were inhibited until the 1: 2 dilution, which corresponds to the concentration 500 mg / ml (Table III). Benzyl alcohol-sodium fluorophosphates toothpaste B inhibited $S$. aureus, $S$. mitis, $S$. salivarius and $S$. pyogenes, with $S$. aureus and $S$. pyogenes being inhibited until the 1: 8 dilution $(125 \mathrm{mg} / \mathrm{ml})$. The toothpaste inhibited S. mitis until 1: 2 dilution (500 mg / $\mathrm{ml}$ ) and inhibited $S$. salivarius until 1: 4 dilution which correspond to the concentration $250 \mathrm{mg}$ / $\mathrm{ml}$. E. coli and P. aeruginosa were not affected by the toothpaste (Table III). Sodium fluoride- eugenol toothpaste inhibited $S$. aureus, S. mitis, $S$. salivarius and $S$. pyogenes, with $S$. aureus and S. mitis inhibited up till 1: 8 dilution (125 mg / $\mathrm{ml}), S$. salivarius and $S$. pyogenes inhibited till 1: 2 dilution $(500 \mathrm{mg} / \mathrm{ml})$. E. coli and $P$. aeruginosa were not affected by the toothpaste (Table IV). Sodium fluoride-sodium laurylsulfate toothpaste inhibited only $S$. pyogenes with bacterium inhibited till 1: 2 dilution $(500 \mathrm{mg} / \mathrm{ml}$ ) (Table 4). Sodium fluoride-potassium nitrate toothpaste inhibited only $S$. pyogenes and $E$. coli. While the toothpaste inhibited $S$. pyogenes till the 1: 4 dilution (250 $\mathrm{mg} / \mathrm{ml})$, E. coli was inhibited till the 1: 8 (125 $\mathrm{mg} / \mathrm{ml}$ ) (Table V). The MIC and $\mathrm{MBC}$ values are shown in figures 1 and 2.

Table I - shows the composition contained in the labels of each toothpaste, as well as the active ingredients, registered according to the manufacturers

\begin{tabular}{|c|c|c|}
\hline Toothpastes & Total composition & Active ingredients \\
\hline A & $\begin{array}{l}\text { Sorbitol, aqua, hydrated silica, sodium } \\
\text { laurylsulfate,PEG-32, aroma, cellulose } \\
\text { gum, sodium saccharin, sodium fluori- } \\
\text { de, zink sulfate, mica, sodium hydroxide } \\
\text { glycerin, eugenol }\end{array}$ & $\begin{array}{l}\text { Sorbitol, sodium fluori- } \\
\text { de, zinc sulfate, sodium } \\
\text { laurylsulfate, and } \\
\text { eugenol }\end{array}$ \\
\hline B & $\begin{array}{l}\text { Sorbitol, aqua, sodium laurylsulfate, } \\
\text { aroma, cellulose gum, sodium hydro- } \\
\text { xide, sodium monofluorophosphate, } \\
\text { calcium carbonate tetrasodium } \\
\text { pyrophosphate, benzyl alcohol sodium } \\
\text { saccharin, limonene. }\end{array}$ & $\begin{array}{l}\text { Sorbitol, benzyl alcohol, } \\
\text { limonene, Sodium mo- } \\
\text { nofluorophosphate, and } \\
\text { sodium laurylsulfate }\end{array}$ \\
\hline C & $\begin{array}{l}\text { Sorbitol, aqua, hydrated silica, sodium } \\
\text { laurylsulfate, aroma, cellulose gum, } \\
\text { sodium saccharin, sodium fluoride, } \\
\text { trisodium phosphate, sodium phospha- } \\
\text { te, carbomer, limonene and eugenol }\end{array}$ & $\begin{array}{l}\text { Sorbitol, sodium fluori- } \\
\text { de, sodium laurylsulfate, } \\
\text { limonene and eugenol. }\end{array}$ \\
\hline D & $\begin{array}{l}\text { Sorbitol, aqua, hydrated silica, sodium } \\
\text { laurylsulphate, PEG-32, aroma, cellu- } \\
\text { lose gum, sodium saccharin, sodium } \\
\text { fluoride, calcium gluconate, glycerin } \\
\text { and limonene. }\end{array}$ & $\begin{array}{l}\text { Sorbitol, sodium fluori- } \\
\text { de, sodium laurylsulfate } \\
\text { and limonene. }\end{array}$ \\
\hline E & $\begin{array}{l}\text { Sorbitol, aqua, hydrated silica, glycerin, } \\
\text { potassium nitrate, cocamidopropyl } \\
\text { betaine, aroma, xanthan gum, titanium } \\
\text { dioxide, sodium fluoride, sodium sac- } \\
\text { charin, sodium hydroxide, sucralose } \\
\text { and limonene. }\end{array}$ & $\begin{array}{l}\text { Sorbitol, sodium fluori- } \\
\text { de, potassium nitrate } \\
\text { and limonene. cocami- } \\
\text { dopropyl betaine }\end{array}$ \\
\hline
\end{tabular}

Key: $\mathbf{A}$ is sodium fluoride-zinc sulphate toothpaste, $\mathbf{B}$ is benzyl alcohol-sodium fluorophosphates toothpaste, $\mathbf{C}$ is sodium fluoride-eugenol toothpaste, $\mathbf{D}$ is sodium fluoride-sodium laurylsulfate toothpaste, $\mathrm{E}$ is sodium fluoride-potassium nitrate toothpaste. 
Table II - Shows the zone of inhibition ( $\mathrm{mm} \pm$ standard deviation) of the bacteria against ciprofloxacin and distilled water

\begin{tabular}{|c|c|c|c|c|c|c|}
\hline \multirow{2}{*}{ Control substances } & \multicolumn{6}{|c|}{ Bacteria } \\
\hline & S. aureus & S. mitis & S. salivarius & S. pyogenes & E. coli & P.aeruginosa \\
\hline Ciprofloxacin $(5 \mu g)$ & $18.4 \pm 1.2$ & $10.6 \pm 0.4$ & $8.5 \pm 1.3$ & $11.7 \pm 0.8$ & $19.2 \pm 1.4$ & $16.2 \pm 0.6$ \\
\hline Distilled water & 0.0 & 0.0 & 0.0 & 0.0 & 0.0 & 0.0 \\
\hline
\end{tabular}

Table III - Shows the mean zone of inhibition $(\mathrm{mm})$ of bacteria at different dilutions of sodium fluoride-zinc sulphate and benzyl alcohol-sodium fluorophosphate toothpastes.

\begin{tabular}{|c|c|c|c|c|c|}
\hline \multirow[b]{2}{*}{ Bacteria } & \multicolumn{5}{|c|}{ Sodium fluoride-zinc sulphate toothpaste } \\
\hline & $\begin{array}{c}1: 1 \\
\text { MEAN } \pm S D\end{array}$ & $\begin{array}{c}1: 2 \\
\text { MEAN } \pm S D\end{array}$ & $\begin{array}{c}1: 4 \\
M E A N \pm S D\end{array}$ & $\begin{array}{c}1: 8 \\
M E A N \pm S D\end{array}$ & $\begin{array}{c}1: 16 \\
\text { MEAN } \pm \text { SD }\end{array}$ \\
\hline S. aureus & $10.3 \pm 0.10$ & $8.6 \pm 0.04$ & $6.9 \pm 0.01$ & $4.7 \pm 0.01$ & $\mathrm{R}$ \\
\hline S. mitis & $10.5 \pm 0.11$ & $4.9 \pm 0.03$ & $\mathrm{R}$ & $\mathrm{R}$ & $\mathrm{R}$ \\
\hline S. salivarius & $12.2 \pm 0.17$ & $10.6 \pm 0.13$ & $8.1 \pm 0.11$ & $5.5 \pm 0.09$ & R \\
\hline S.pyogenes & $8.6 \pm 0.03$ & $6.4 \pm 0.03$ & $\mathrm{R}$ & $\mathrm{R}$ & R \\
\hline E. coli & $\mathrm{R}$ & $\mathrm{R}$ & $\mathrm{R}$ & $\mathrm{R}$ & $\mathrm{R}$ \\
\hline \multirow[t]{2}{*}{ P.aeruginosa } & $\mathrm{R}$ & $\mathrm{R}$ & $\mathrm{R}$ & $\mathrm{R}$ & $\mathrm{R}$ \\
\hline & \multicolumn{5}{|c|}{ Benzyl alcohol-sodium fluorophosphate toothpaste } \\
\hline S. aureus & $12.7 \pm 0.08$ & $9.8 \pm 0.05$ & $7.3 \pm 0.03$ & $4.7 \pm 0.02$ & $\mathrm{R}$ \\
\hline S. mitis & $6.9 \pm 0.02$ & $5.2 \pm 0.04$ & $\mathrm{R}$ & $\mathrm{R}$ & $\mathrm{R}$ \\
\hline S. salivarius & $12.8 \pm 0.15$ & $10.1 \pm 0.10$ & $7.4 \pm 0.12$ & $\mathrm{R}$ & $\mathrm{R}$ \\
\hline S. pyogenes & $16.6 \pm 0.11$ & $14.2 \pm 0.09$ & $11.6 \pm 0.05$ & $8.1 \pm 0.03$ & $\mathrm{R}$ \\
\hline E. coli & $\mathrm{R}$ & $\mathrm{R}$ & $\mathrm{R}$ & $\mathrm{R}$ & $\mathrm{R}$ \\
\hline Paeruginosa & $\mathrm{R}$ & $\mathrm{R}$ & $\mathrm{R}$ & $\mathrm{R}$ & R \\
\hline
\end{tabular}

Key: $R=$ Resistant.

Table IV - Shows the mean zone of inhibition $(\mathrm{mm})$ of bacteria at different dilutions of sodium fluoride-eugenol and sodium fluoridesodium laurylsulfate toothpastes.

\begin{tabular}{|c|c|c|c|c|c|}
\hline \multirow[b]{2}{*}{ Bacteria } & \multicolumn{5}{|c|}{ Sodium fluoride-eugenol toothpaste } \\
\hline & $\begin{array}{c}1: 1 \\
\text { MEAN } \pm \text { SD }\end{array}$ & $\begin{array}{c}1: 2 \\
\text { MEAN } \pm S D\end{array}$ & $\begin{array}{c}1: 4 \\
\text { MEAN } \pm \text { SD }\end{array}$ & $\begin{array}{c}1: 8 \\
\text { MEAN } \pm \text { SD }\end{array}$ & $\begin{array}{c}1: 16 \\
M E A N \pm S D\end{array}$ \\
\hline S. aureus & $9.3 \pm 0.05$ & $7.5 \pm 0.03$ & $6.1 \pm 0.04$ & $5.3 \pm 0.02$ & $\mathrm{R}$ \\
\hline S. mitis & $18.2 \pm 0.14$ & $10.9 \pm 0.12$ & $8.4 \pm 0.09$ & $6.2 \pm 0.10$ & $\mathrm{R}$ \\
\hline S. salivarius & $8.4 \pm 0.07$ & $6.2 \pm 0.05$ & $\mathrm{R}$ & $\mathrm{R}$ & $\mathrm{R}$ \\
\hline S. pyogenes & $10.8 \pm 0.04$ & $8.3 \pm 0.01$ & $\mathrm{R}$ & $\mathrm{R}$ & $\mathrm{R}$ \\
\hline E. coli & $\mathrm{R}$ & $\mathrm{R}$ & $\mathrm{R}$ & $\mathrm{R}$ & $\mathrm{R}$ \\
\hline \multirow[t]{2}{*}{ P.aeruginosa } & $\mathrm{R}$ & R & R & $\mathrm{R}$ & R \\
\hline & \multicolumn{5}{|c|}{ Sodium fluoride-sodium laurylsulfate toothpaste } \\
\hline S. aureus & R & R & $\mathrm{R}$ & $\mathrm{R}$ & $\mathrm{R}$ \\
\hline S. mitis & $\mathrm{R}$ & $\mathrm{R}$ & $\mathrm{R}$ & $\mathrm{R}$ & $\mathrm{R}$ \\
\hline S. salivarius & $\mathrm{R}$ & $\mathrm{R}$ & $\mathrm{R}$ & $\mathrm{R}$ & $\mathrm{R}$ \\
\hline S. pyogenes & $10.6 \pm 0.07$ & $7.5 \pm 0.05$ & $\mathrm{R}$ & $\mathrm{R}$ & $\mathrm{R}$ \\
\hline E. coli & $\mathrm{R}$ & $\mathrm{R}$ & $\mathrm{R}$ & $\mathrm{R}$ & $\mathrm{R}$ \\
\hline P.aeruginosa & $\mathrm{R}$ & $\mathrm{R}$ & $\mathrm{R}$ & $\mathrm{R}$ & $\mathrm{R}$ \\
\hline
\end{tabular}

Key: $R=$ Resistant. 
Table IV - Shows the mean zone of inhibition $(\mathrm{mm})$ of bacteria at different dilutions of sodium fluoride-eugenol and sodium fluoridesodium laurylsulfate toothpastes.

\begin{tabular}{|cccccc}
\hline Bacteria & \multicolumn{2}{c}{ Sodium fluoride-potassium nitrate toothpaste } \\
& $\begin{array}{c}1: 1 \\
\text { MEAN } \pm \text { SD }\end{array}$ & $\begin{array}{c}1: 2 \\
\text { MEAN } \pm \text { SD }\end{array}$ & $\begin{array}{c}1: 4 \\
\text { MEAN } \pm \text { SD }\end{array}$ & $\begin{array}{c}1: 8 \\
\text { MEAN } \pm \text { SD }\end{array}$ & $\begin{array}{c}\text { 1:16 } \\
\text { MEAN } \pm \text { SD }\end{array}$ \\
\hline S. aureus & $\mathrm{R}$ & $\mathrm{R}$ & $\mathrm{R}$ & $\mathrm{R}$ & $\mathrm{R}$ \\
\hline S. mitis & $\mathrm{R}$ & $\mathrm{R}$ & $\mathrm{R}$ & $\mathrm{R}$ & $\mathrm{R}$ \\
\hline S. salivarius & $\mathrm{R}$ & $\mathrm{R}$ & $\mathrm{R}$ & $\mathrm{R}$ & $\mathrm{R}$ \\
\hline S. pyogenes & $14.5 \pm 0.13$ & $12.1 \pm 0.08$ & $8.8 \pm 0.17$ & $\mathrm{R}$ & $\mathrm{R}$ \\
\hline E. coli & $18.2 \pm 0.15$ & $16.4 \pm 0.10$ & $12.7 \pm 0.14$ & $\mathrm{R} .4 \pm 0.16$ & $\mathrm{R}$ \\
\hline Paeruginosa & $\mathrm{R}$ & $\mathrm{R}$ & $\mathrm{R}$ & $\mathrm{R}$ & $\mathrm{R}$ \\
\hline
\end{tabular}

Key: R = Resistant.

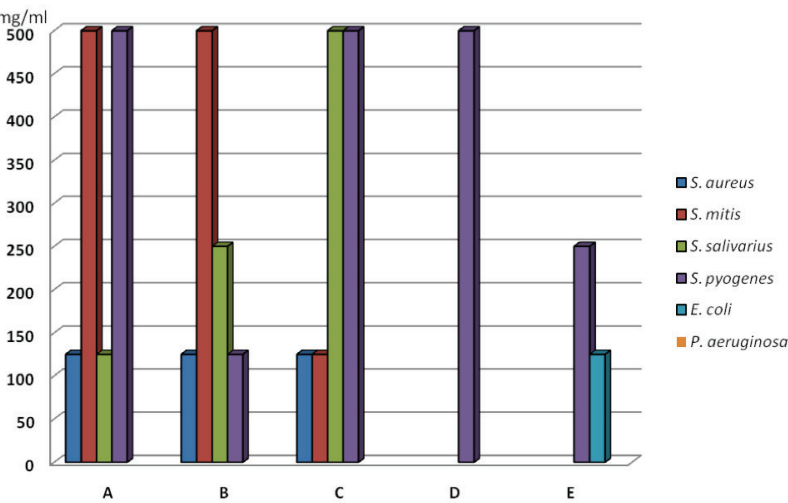

Figure 1 - Minimum inhibitory concentration (MIC) of sodium fluoride-zinc sulphate, benzyl alcohol-sodium fluorophosphates, sodium fluoride-eugenol, sodium fluoridesodium laurylsulfate and sodium fluoride-potassium nitrate toothpastes against the tested microorganisms.

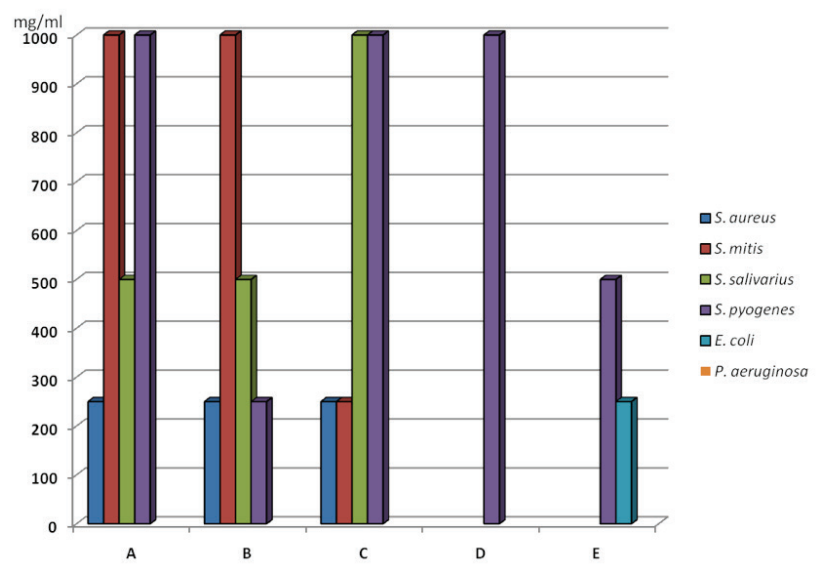

Figure 2 - Shows the minimum bactericidal concentration (MBC) of sodium fluoride-zinc sulphate, benzyl alcohol-sodium fluorophosphates, sodium fluoride-eugenol, sodium fluoridesodium laurylsulfate and sodium fluoride-potassium nitrate toothpastes against the tested microorganisms.

\section{DISCUSSION}

There are several toothpastes available in different markets whose manufacturers claim to have antimicrobial potential. The present study was carried out to assess the antibacterial potential of five different brands of toothpaste sold in Ado-Ekiti. The in vitro agar diffusion method was used because it is easier to directly measure the antibacterial potential of each toothpaste dilution. The toothpaste showing the largest zone of inhibition had the strongest antimicrobial properties.

Antimicrobial effects related to toothpastes have been demonstrated in the literature [26]. The toothpastes tested in this study have components which are expected to sufficiently control the oral microbiome, when present in adequate concentrations. The results of the present study indicated that the different toothpastes exhibited varied effectiveness against the different microorganisms. It is believed that components such as sodium fluoride, zinc sulfate and sodium monoflurophosphate, eugenol, sorbitol, benzyl alcohol, sodium laurylsulfate, limonene, cocamidopropyl betaine and potassium nitrate may be related to antibacterial effects. All toothpastes investigated in the present study contain essentially the same active ingredients with little variation, but have demonstrated varying degrees of effectiveness against the tested microorganisms. Fluoride and 
sorbitol are present in all toothpastes in this study, according to the manufacturers. Sodium fluoride-zinc sulphate, benzyl alcohol-sodium fluorophosphates and sodium fluoride-eugenol toothpastes showed greater antibacterial effects when compared to sodium fluoride-sodium laurylsulfate and sodium fluoride potassium nitrate toothpastes. This may have been due to the presence of active components with greater antimicrobial capacity. Sodium fluoridezinc sulphate toothpaste and sodium fluorideeugenol have in their composition the substance eugenol, whose strong antiseptic potential has been reported in the literature [27]. Only benzyl alcohol-sodium fluorophosphate toothpaste possesses benzyl alcohol as constituent. The alcohol has antibacterial potential and is also added to toothpastes for its fragrance [28].

All the toothpastes have limonene as a constituent except sodium fluoride-zinc sulphate toothpaste. Limonene is a chemical substance found in the peels of citrus fruits. Its major use in toothpaste is as solvent for cleansing purpose and as fragrance, but is known to have antimicrobial activities [30]. Sorbitol is a sugar-alcohol compound used as a sweetener in toothpaste, but it has a preventive effect against caries [29].

There are conflicting results on the antibacterial effects of different concentrations of sodium fluoride toothpastes against some oral microbiome [31]. This was re-affirmed by Imran et al. [32]. Toothpastes having higher concentrations of fluoride may record higher antibacterial potentials. The present study agreed with the report of Marinho et al. [4] that fluoride toothpaste is associated with inhibition of oral microbiome and capable of achieving reduction in tooth decay. The reported ability of benzyl alcohol-sodium fluorophosphates toothpaste (containing sodium monofluorophosphate and sodium laurylsulfate) in the reduction of dental decay [4] appears supported by the present study. When formulated correctly and used as directed, fluoride toothpastes will help to prevent tooth decay. It is well documented that fluoride has the ability to inhibit or even reverse the initiation and progression of dental caries [33].

In our study, sodium fluoride-zinc sulphate, benzyl alcohol-sodium fluorophosphate, sodium fluoride-eugenol and sodium fluoride-sodium laurylsulfate toothpastes did not inhibit E. coli, only sodium fluoride-potassium nitrate toothpaste at $1000 \mathrm{mg} / \mathrm{ml}, 500 \mathrm{mg} / \mathrm{ml}$, $250 \mathrm{mg} / \mathrm{ml}$ and $125 \mathrm{mg} / \mathrm{ml}$ inhibited the bacterium. Among the toothpastes used in this study, only sodium fluoride-potassium nitrate toothpaste contained potassium nitrate and cocamidopropyl betaine in its formulations. Potassium nitrate has been reported to have strong antimicrobial activities against E. coli [34] and cocamidopropyl betaine has antibacterial activity [35].

All the toothpastes at different dilutions showed no inhibitory effects on $P$ aeruginosa. This could be due to its intrinsic resistance to many antimicrobial agents, mainly due to the synergistic effect of multi-drug efflux system and the bacteria's low outer membrane permeability [36]

The MIC and MBC results revealed that sodium fluoride-zinc sulphate, benzyl alcohol-sodium fluorophosphates and sodium fluoride-eugenol toothpastes had bacteriostatic and bactericidal effects on $S$. aureus, S. mitis, S. salivarius and S. pyogenes. Of these three toothpastes, sodium fluorideeugenol was shown to be the most inhibitory for microorganisms, followed by benzyl alcohol-sodium fluorophosphates and sodium fluoride-zinc sulphate. Sodium fluoridesodium laurylsulfate and sodium fluoridepotassium nitrate toothpastes did not show inhibitory activity against $S$. aureus, S. mitis, $S$. salivarius, but both toothpastes inhibited $S$. pyogenes. The low inhibition potential of 
sodium fluoride-sodium laurylsulfate toothpaste compared to other toothpastes is supported by Bhattcharjee et al. [37]. All toothpastes contain sodium laurysulfate (SLS) in their constitution, except sodium fluoride-potassium nitrate toothpaste. SLS has been reported to have strong antimicrobial properties [38]. This may be the explanation for the lower inhibitory effects presented by sodium fluoride-potassium nitrate toothpaste. Although the substance is present in Sodium fluoride-sodium laurylsulfate toothpaste, there was no inhibition by it. It may be that the concentration of SLS present in this toothpaste is not satisfactory to cause any significant inhibitory effect on bacteria.

The sterility test carried out on the toothpaste showed that they were all sterile. This is in agreement with the findings of Okpalugo et al. [39]. The test was important to guarantee the quality of these products. No visible growth was observed in the present study in any of the toothpastes, indicating that manufacturers' claims about quality with respect to sterility can be trusted.

Since dilutions can affect the effectiveness of toothpastes on the bacteria tested in the in vitro study, toothpastes that showed higher rates of inhibition, being considered to have higher antibacterial properties, may not necessarily be higher than those that had lower rates of inhibition. In addition, it should be taken into account that toothpaste when used in vivo is likely to be diluted by saliva, reducing or losing such antimicrobial properties [40]. In addition, different toothpastes have different active ingredients and other substances, which can spread at different rates, resulting in different potential antimicrobials. Therefore, it cannot be fully assumed that the results of antimicrobial efficacy can be directly proportional or transferable to the clinical efficacy of toothpaste. The accumulation of oral microorganisms represents the main etiological factor for oral diseases, including cavities and periodontal diseases. Thus, the use of toothpastes with adequate formulations is essential, since oral hygiene is considered the main factor that influences the degree of dental caries and the control of periodontal disease. The manufacturers' claims about the potential antibacterial properties of toothpaste against microorganisms capable of causing infection in the oral cavity appeared to be supported by this research for sodium fluoride-zinc sulphate, benzyl alcohol-sodium fluorophosphates and sodium fluoride-eugenol toothpastes. However, the same antibacterial potential against these microorganisms was not demonstrated by sodium fluoride-sodium laurylsulfate toothpaste, except for $S$. pyogenes and sodium fluoride-potassium nitrate toothpaste, which was effective against $S$. pyogenes and E. coli. Thus, sodium fluoridesodium laurylsulfate and sodium fluoridepotassium nitrate toothpastes may not satisfy the claim required by the manufacturers.

The limitation to this study is that antibacterial effects of the toothpastes on many other periodontal anaerobic pathogens such as $P$. gingivalis, T. forsythia, T. denticola and facultative anaerobic pathogen, A. actinomycetemcomitans, were not determined in this study. Also, tests for the presence of the constituents claimed by the manufacturers or the concentrations of the constituents were not included in this study.

\section{CONCLUSION}

Most of the toothpastes in Ado-Ekiti are essentially similar in composition, but differ in relation to the inhibition potentials on the microorganisms tested. While some toothpastes had greater antimicrobial effects, others had less potential against the tested microorganisms. This variation may be related to the concentration of active components used in the preparation of different toothpastes. In general, the manufacturers' claims about the potential antibacterials of toothpaste against microorganisms capable of causing infection 
in the oral cavity appear to be supported by this research for toothpastes sodium fluoride-zinc sulphate, benzyl alcohol-sodium fluorophosphate, sodium fluoride-eugenol.

\section{REFERENCES}

1. Aas JA, Paster BJ, Stokes LN, Olsen I, Dewhirst FE. Defining the normal bacterial flora of the oral cavity. J Clin Microbiol. 2005 Nov;43(11):5721-32 doi: 10.1128/JCM.43.11.5721-5732.2005

2. Mager DL, Ximenez-Fyvie LA, Haffajee AD, Socransky SS. Distribution of selected bacterial species on intraoral surfaces. J Clin Periodontol. 2003 Jul;30(7):644-54. doi: 10.1034/j.1600-051x.2003.00376.x

3. Morris AJ, Steele J, White DA. The oral cleanliness and periodontal health of UK adults in 1998. Br Dent J. 2001 Aug;191(4):186-92. doi: 10.1038/ sj.bdj.4801135

4. Marinho VCC, Higgins J, Logan S, Sheiham A. 2003. Fluoride toothpastes for preventing dental caries in children and adolescents (Review). Cochrane Database Syst Rev. 2003;(1):CD002278. doi:10.1002/14651858.CD002278

5. Iqbal K, Asmat M, Jawed S, Mushtaque A, Mohsin F, Hanif S, Sheikh N. Role of different ingredients of tooth pastes and mouthwashes in oral health. JPDA 2011 July-Sept., 20(3):163-170.

6. Singh S, Chaknis P,DeVizio W, Petrone M, Panagakos FS, Proskin HM. A clinical investigation of the efficacy of three commercially available dentifrices for controlling established gingivitis and supragingival plaque.J Clin Dent. 2010;21(4):105-10.

7. Fine DH, Sreenivasan PK, McKiernan M, Tischio-Bereski D, Furgang D. Whole mouth antimicrobial effects after oral hygiene: comparison of three dentifrice formulations. J Clin Periodontol. 2012 Nov;39(11):1056-64. doi: 10.1111/.1.1600-051X.2012.01938.x

8. Slade GD, Spencer AJ, Roberts-Thomson KF.Australia's dental generations: the national survey of adult oral health 2004-06. Dental statistics and research series, Canberra: Australian Institute of Health and Welfare. 2007. 274p.

9. Al-Shahrani MA. Microbiology of Dental Caries: A Literature Review. Ann Med Health Sci Res. 2019:9:655-59.

10. Lovegrove JM. Dental plaque revisited: bacteria associated with periodonta disease. J NZ Soc Periodontol. 2004;(87):7-21. PMID: 15143484.

11. Inagaki S, Onishi S, Kuramitsu HJ, Sharma A. Porphyromonas gingivalis vesicles enhance attachment, and the leucine-rich repeat BspA protein is required for invasion of epithelial cells by Tannerella forsythia. Infect Immun. 2006 Sept;74(9):5023-8. doi: 10.1128/IAl.00062-06

12. Bensing BA, Rubens CE, Sullam PM. Genetic loci of Streptococcus mitis that mediate binding to human platelets. Infect Immun. 2001Mar;69(3):1373-80. doi:10.1128/IAl.69.3.1373-1380.2001

13. Chastanet A, Msadek T.Clpp of Streptococcus salivarius is a Novel Member of the dually regulated Class of stress response genes in Gram positive bacteria. JBacteriol. 2003 Jan;185(2):683-7. doi:10.1128/JB.185.2.683687.2003

14. Facklam R, What happened to the streptococci: overview of taxonomic and nomenclature changes. Clin Microbiol Rev. 2002 0ct;15(4):613-30. doi: 10.1128/CMR.15.4.613-630.2002
15. Tong S, Davis J, Eichenberger E, Holland T, Fowler V. 2015. Staphylococcus aureus infections: epidemiology, pathophysiology, clinical manifestations, and management. Clin Microbiol Rev. 2015 Jul;:28(3):603-61. doi: 10.1128/ CMR.00134-14

16. Worldatlas 2015. Available from: http://www.worldatlas.com/af/ng/ek/ where-is-ado-ekiti.html. Access 19th August, 2019.

17. Olusegun 0. Urban expansion and urban land use in Ado Ekiti, Nigeria. Am J Res Communication. 2013;(2):128-39.

18. Baird D. Staphylococcus: Cluster-forming Gram-positive cocci. In:Collee JG, Dugiud JP, Fraser AG, Marmion BP (ed). Practical Medical Microbiology. 14th ed. Elsevier:India. 2014. p.245-261.

19. Cheesbrough M. District Laboratory Practice in Tropical Countries. 2 ed. Part 2. Cambridge University Press: Cambridge, New York. 2006.

20. Collee JG, Miles RS, WattB. Tests for identification of bacteria In: Collee JG, Dugiud JP, Fraser AG, Marmion BP (ed). Practical Medical Microbiology. 14 ed. Elsevier: India. 2014. p.131-149.

21. Crichton BP.Enterobacteriaceae: Escherichia coli, Klebsiella, Proteus, and other genera. In: Collee JG, Dugiud JP, Fraser AG, Marmion BP (ed), Practica Medical Microbiology. 14 ed. Elsevier:India. 2014. p361-384.

22. Govan JR. Pseudomonas, Stenotrophononas, Burkholderia. In: Collee JG, Dugiud JP, Fraser AG, Marmion BP (ed), Practical Medical Microbiology. 14 ed. Elsevier: India. 2014. P 413-424.

23. Ross PW. Streptococcus and Enterococcus. In: Collee JG, Dugiud JP, Fraser AG, Marmion BP (ed), Practical Medical Microbiology. 14 ed. Elsevier: India. 2014. p 263-274.

24. Mohammed A, Sahile S, Subramanian C. Evaluation of antibacterial potential of honey against some common human pathogens in North Gondar zone of Ethiopia. Int J Pure Appli Zoology. 2014;2(4):286-95.

25. Miles RS, Amyes SGS. Laboratory control of antimicrobial therapy. In: Collee JG, Dugiud JP, Fraser AG, Marmion BP (ed). Practical Medical Microbiology. 14th ed. Elsevier:India. 2014. p 151-178.

26. Fine DH, Furgang D, Markowitz K, Sreenivasan PK, Klimpel K, De Vizio W. The antimicrobial effect of a triclosan/copolymer dentifrice on oral microorganism in vivo. J Am Dent Assoc. 2006 0ct;137(10):1406-13. doi:10.14219/jada.archive.2006.0053

27. Jadhav BK, Khandelwal KR, Ketkar AR, Pisal SS. Formulation and evaluation of mucoadhesive tablets containing eugenol for the treatment of periodontal diseases. Drug Dev Ind Pharm. 2004 Feb;30(2):195-203. doi:10.1081/DDC-120028715

28. Johnson W, Bergfeld WF, Belsito DV, Hill RA, Klaassen CD, Liebler DC, Marks JG, Shank RC, Slaga TJ, Snyder PW, Andersen FA. Safety Assessment of Benzyl Alcohol, Benzoic Acid and its Salts, and Benzyl Benzoate. Int J Toxicol. 2017 Nov/Dec;36(3_suppl):5S-30S. doi: 10.1177/1091581817728996. PMID: 29243541

29. van Loveren C. Sugar alcohols: What is the evidence for caries-preventive and caries therapeutic effects? Caries Res. 2004 May-Jun;38:286-93. doi: 10.1159/000077768

30. Settanni L, Palazzolo E, Guarrasi V, Aleo A, Mammina C, Moschetti G. etal. Inhibition of foodborne pathogen bacteria by essential oils extracted from citrus fruits cultivated in Sicily. Food Control. 2012;26:326-30. doi:10.1016/j. foodcont.2012.01.050

31. Iliana D, Haroula K, Eleni M. Effects of toothpastes containing different NaF concentrations or a SnF2/NaF combination on root dentine erosive lesions, in-vitro. J Clin Exp Dent. 2016 Dec;8(5):e577-e583. doi: 10.4317/jced.53047

32. 32. FarooqI, Ali S, Al-Khalifa KS, Alhooshani K. Total and soluble fluoride 
concentration present in various commercial brands of children toothpastes available in Saudi Arabia - A pilot study. Saudi Dent J. 2018 Apr;30(2):161-165 doi:10.1016/j.sdentj.2018.01.001. Epub 2018 Jan 31. PMID: 29628740; PMCID: PMC5884239.

33. Marinho VC. Cochrane reviews of randomized trials of fluoride therapies for preventing dental caries. Eur Arch Paediatr Dent. 2009 Sept;10(3):183-191. https://doi.org/101007/BF03262681

34. Tasie F0, Anunike IA, Nwankwo JL. Antimicrobial effects of toothpastes on some oral organisms of dental caries origin. IDOSR J Experimental Sci. 2017;2(1):1-20.

35. Dai M, Guo J, Xue X, Feng V.Preparation and Investigation of High-Efficiency Antibacterial Liquid Dishwashing Detergent. Trans. Transactions of Tianjin University. 2019;25:322-9. https://doi.org/10.1007/s12209-019-00187-x

36. Viren A, Somsuvra B, Kamlesh R, Jagruti A. Antibiotic susceptibility patterns of Pseudomonas aeruginosa at a tertiary care hospital in Gujarat, India. Indian JPharmacol. 2008 0ct;40(5):230-4. doi: 10.4103/0253-7613.44156
37. Bhattacharjee S, Nath S, Bhattacharjee P,Chouhan M, Deb B. Efficacy of Toothpastes on Bacteria Isolated from Oral Cavity. Int J Med Public Health. 2018;8(2):89-92. doi:10.5530/ijmedph.2018.2.19

38. Nordstrom A, Mystikos C, Ramberg P,Birkhed D. 2009. Effect on de novo plaque formation of rinsing with toothpaste slurries and water solutions with a high fluoride concentration (5,000 ppm). Eur J Oral Sci. 2009 0ct;117(5):563-7.D0l: 10.1111/j.1600-0722.2009.00674.x

39. Okpalugo J, Ibrahim K, Inyang US. 2009. Toothpaste formulation efficacy in reducing oral flora. Trop J Pharm Res. 2009 Feb;8(1):71-7. doi: 10.4314/tjpr. v8i1.14714

40. Gehlen I, Netuschil L, Berg R, Reich E, Katsaros C. The influence of a $0.2 \%$ chlorhexidine mouthrinse on plaque regrowth in orthodontic patients. $A$ randomized prospective study. Part l: clinical parameters. J Orofac Orthop. 2000;61(1):54-62. doi: 10.1007/bf02340932

\section{Oluboyo Bernard Oluwapelumi}

(Corresponding address)

Department of Medical Laboratory Science, College of Medicine and Health Sciences, Afe Babalola University, Ado-Ekiti, Ekiti State, Nigeria. 